\title{
Detection of the Cassava Bacterial Blight Pathogen, Xanthomonas axonopodis pv. manihotis, by Polymerase Chain Reaction
}

V. Verdier, Laboratoire de Phytopathologie Tropicale, Institut Français de Recherche Scientifique pour le Développement en Coopération (ORSTOM), BP5045, 35032 Montpellier, France; G. Mosquera, Unidad de Biotecnologia, Centro Internacional de Agricultura Tropical (CIAT), A.A. 6713, Cali, Colombia; and K. Assigbétsé, ORSTOM, BP5045, 35032 Montpellier, France

\begin{abstract}
Verdier, V., Mosquera, G., and Assigbétsé, K. 1998. Detection of the cassava bacterial blight pathogen, Xanthomonas axonopodis pv. manihotis, by polymerase chain reaction. Plant Dis. $82: 79-83$

Cassava bacterial blight, caused by Xanthomonas axonopodis pv. manihotis, is of significant concern wherever cassava is grown. The movement of infected, asymptomatic stems is a major means of pathogen dispersal. A reliable and sensitive diagnostic procedure is necessary for the safe movement of cassava planting material. We used a cloned and sequenced pathogenicity gene of X. axonopodis pv. manihotis to develop a polymerase chain reaction (PCR) test for this pathogen. A set of primers directed the amplification of an 898-bp fragment in all 107 pathogenic strains of $X$. axonopodis pv. manihotis tested. PCR products were not observed when genomic DNA was tested for 27 strains of other xanthomonads, for saprophytic bacteria, or for five nonpathogenic strains of $X$. axonopodis pv. manihotis. The primers worked well for pathogen detection in direct PCR assays of $X$. axonopodis pv. manihotis colonies grown on liquid medium and in PCR assays of extracts from leaf and stem lesions. The minimum number of cells that could be detected from cassava stem and leaf lesions was $3 \times 10^{2}$ to $10^{4} \mathrm{CFU} / \mathrm{ml}$. The PCR assays proved to be relatively sensitive and could become very useful in detecting the pathogen in cassava planting material.
\end{abstract}

Cassava (Manihot esculenta Crantz) is a starchy root crop that provides food and income for about 500 million people living in the tropics. Xanthomonas axonopodis pv. manihotis Dye (42) is the causal agent of cassava bacterial blight, an economically important disease with a worldwide distribution (20,24). The disease was first reported in South America and has subsequently been reported in Africa and Asia $(5,20)$; it is now a target for international phytosanitary quarantine efforts (20). The disease has a wide spectrum of symptoms, including angular leaf spots, blighting, wilting, vascular necrosis of the stem, dieback, and production of exudates (24). Crop losses of 12 to $100 \%$ have been reported (20). This vascular disease also affects the quality of the planting material, leading to reductions in seed yield $(5,20)$. Cassava is propagated by planting pieces of stem, and the pathogen is thus disseminated primarily

Corresponding author: V. Verdier; current address: CIAT, Unidad de Biotecnologia, A.A. 6713, Cali, Colombia; tel.: 572 4450037; fax: 572 4450073; E-mail: v.verdier@cgnet.com

Accepted for publication 30 September 1997.

Publication no. D-1997-1110-01R

This article is in the public domain and not copyrightable. It may be freely reprinted with customary crediting of the source. The American Phytopathological Society, 1998. through infected planting material $(5,20)$. Previous studies have shown that $X$. axonopodis pv. manihotis is also seedborne and is carried either on the seed coat or in the embryo (29). This contamination, whether internal or external, is an important means of survival for this bacterium $(8,9,11)$. The pathogen also affects the germination of infected seeds (11).

The disease can be controlled through cultural practices, including the use of uninfected planting material and resistant cultivars $(5,20)$. Although the production of healthy planting material in inspected nurseries can reduce the incidence of the disease, this method has its limitations because $X$. axonopodis pv. manihotis can survive in tissue without causing symptoms (5). Thus, sensitive detection techniques are needed to prevent the introduction of the pathogen into regions free of bacterial blight. As a consequence of quarantine procedures, international exchange of cassava germ plasm is limited and occurs through true seeds or material propagated in vitro (20). The success of a cassava seed certification program will depend on the availability of reliable tests for detecting the pathogen in true seeds and vegetative material.

Current methods for identifying and detecting $X$. axonopodis pv. manihotis rely on isolating the bacterium and conducting immunoassays of tissue extracts $(8,9,11)$. Enzyme-linked immunosorbent assays for
$X$. axonopodis pv. manihotis may improve detection and are rapid, but immunological reactions are not entirely specific because of cross-reactions with some strains of other pathovars of $X$. axonopodis and one strain of $X$. campestris pv. euphorbiae (6). Newer molecular tools, including Southern hybridization probes, are very efficient for identifying plant pathogens $(12,23)$. Recently, DNA probes derived from genomic and plasmid DNA have been developed for $X$. axonopodis pv. manihotis and have been useful in restriction fragment length polymorphism (RFLP) studies (41). The genetic variability among strains of $X$. axonopodis pv. manihotis has been characterized in detail $(39,41)$, revealing that the African strains are homogenous, whereas in South America, the pathogen is highly diverse.

The polymerase chain reaction (PCR) method has been widely used to identify and detect phytopathogenic bacteria $(2,3$, 10,13,15,30). Various PCR methods have been developed for different phytopathogenic bacteria based on the amplification of $h r p$ sequences $(16,18)$, repetitive bacterial sequences (rep-PCR) $(27,31)$, tRNA intergenic and rDNA spacer sequences $(15,19,21,30)$, specific plasmid sequences $(3,13)$, and specific random amplified polymorphic DNA products $(23,31)$.

The pathogenicity of $X$. axonopodis pv. manihotis is associated with a plasmid (p44) that is widely distributed within $X$. axonopodis pv. manihotis strains (38). In a nonpathogenic $X$. axonopodis pv. manihotis strain, a 8-kb region is missing from the plasmid, suggesting that this sequence is involved in pathogenicity. This sequence is included in a 12-kb HindIII plasmid fragment (psF2) (40). We established a restriction map for the plasmid fragment psF2, subcloned selected fragments, and determined the nucleotide sequences of the fragments (40). For this study, we developed primers for PCR based on the sequence of one of these, a $1.2-\mathrm{kb} X$. axonopodis pv. manihotis plasmid fragment. We thus developed a sensitive and rapid PCR-based assay for detecting the blightcausing bacterium in cassava stem and leaf tissues.

\section{MATERIALS AND METHODS}

Bacterial strains and DNA extraction. All of the 158 bacterial strains we used are listed in Table 1. Bacteria living as epi- 
phytes on cassava foliage were recovered from collected leaves and used for testing primer specificity. Colombian isolates of $X$. axonopodis pv. manihotis (CIO strains), collected during 1995 in different edaphoclimatic zones, were included. Sixteen Xanthomonas strains were used, as well as 19 strains representing 14 pathovars of $X$. axonopodis. All cultures were stored at $-70^{\circ} \mathrm{C}$ in nutrient broth containing $60 \%$ glycerol. Strains were cultured routinely at $30^{\circ} \mathrm{C}$ on
LPG medium ( $5 \mathrm{~g}$ of glucose, $5 \mathrm{~g}$ of yeast extract, $5 \mathrm{~g}$ of peptone, and $15 \mathrm{~g}$ of agar per liter). Freshly grown, single colonies on LPG media were used to start broth cultures. Bacterial cultures were grown at $30^{\circ} \mathrm{C}$ for $12 \mathrm{~h}$, and cells from $3 \mathrm{ml}$ of broth were used for DNA extraction. Total genomic DNA was isolated as described by Berthier et al. (4).

PCR reaction conditions. Primers for the PCR were designed with the software
OLIGO, version 4.0 (National Biosciences, Plymouth, NC), based on the sequence of $X$. axonopodis pv. manihotis's 1,276-nucleotide BamHI-EcoRI insert in pBSF2. The primers were obtained commercially from Eurogentec (Louvain, Belgium). Sequence analysis was performed with the Bisance service of CITI2 (Faculté de Médecine, Paris, France). The sequence from which the primers were selected showed no homology to other available DNA se-

Table 1. Bacterial strains used in this study

\begin{tabular}{|c|c|c|}
\hline Strain & Isolates $^{\mathrm{a}}$ & Location \\
\hline Xanthomonas axonopodis pv. manihotis & $\begin{array}{l}\text { I67, I71, I70 } \\
\text { I89, K1, K7 } \\
\text { I1, I10, I13, I25, I36, I41, I42, I63 } \\
\text { Orst17, Orst151, Orst161, Orst178, Orst200 } \\
\text { OrstX27, OrstX102, OrstX75, OrstX84, OrstX80 } \\
\text { LMG769, Orst44, Orst50, Orst186, UPB009 } \\
\text { Orst267, Orst212, Orst213, Orst214, Orst215, Orst216 } \\
\text { Orst324, Orst241, LMG780, Orst242, Orst243 } \\
\text { Orst56, LMG5249 } \\
\text { Orst39, Orst40, Orst41 } \\
\text { LMG5288 } \\
\text { LMG783 } \\
\text { CFBP2624, Orst227, Orst228 } \\
\text { CIO46 + 25 other CIO strains, CIO188, CIAT1059* } \\
\text { CIAT1063, CIAT1066, Orst4, CFBP1851 } \\
\text { NCPPB348, CIO286, CIO287, CIO288, CIO289, CIO290 } \\
\text { NCPPB1159, LMG 777, UPB079,* UPB070 } \\
\text { CIAT1241, INTA1, INTA2, INTA3, INTA4, INTA5 } \\
\text { CIAT1129, CIO191, CIO237, CIO231, CIO246 } \\
\text { CIAT1162 } \\
\text { CIAT1135 } \\
\text { CIAT1161 } \\
\text { CIAT1163 } \\
\text { CIAT1160, LMG765 } \\
\text { CIAT1181 } \\
\text { CIAT1203 } \\
\text { UPB071 }\end{array}$ & $\begin{array}{l}\text { Ghana } \\
\text { Nigeria } \\
\text { Benin } \\
\text { Congo } \\
\text { Togo } \\
\text { Zaire } \\
\text { Cameroon } \\
\text { Uganda } \\
\text { Ivory Coast } \\
\text { Central Africa } \\
\text { Niger } \\
\text { Kenya } \\
\text { Réunion } \\
\text { Colombia } \\
\text { Colombia } \\
\text { Brazil } \\
\text { Brazil } \\
\text { Argentina } \\
\text { Venezuela } \\
\text { Mexico } \\
\text { China } \\
\text { Thailand } \\
\text { Sumatra (Indonesia) } \\
\text { Malaysia } \\
\text { Philippines } \\
\text { Dominican Republic } \\
\text { Mauritius }\end{array}$ \\
\hline$X$. axonopodis pv. citri & CFBP1814 & Réunion \\
\hline$X$. axonopodis pv. campestris & CFBP10412 & United Kingdom \\
\hline X. axonopodis pv. aracearum & NCPPB2832 & Guadeloupe \\
\hline X. axonopodis pv. begoniae & NCPPB3003 & Netherlands \\
\hline$X$. axonopodis pv. hordei & UPB684 & Iran \\
\hline$X$. axonopodis pv. diffenbachiae & NCPPB 1833 & Brazil \\
\hline$X$. axonopodis pv. glycines & NCPPB554, Orst1144 & Sudan, Congo \\
\hline X. axonopodis pv. vesicatoria & CFBP10601 & Unknown \\
\hline X. axonopodis pv. malvacearum & NCPPB633, Orst57 & Ivory Coast \\
\hline X. axonopodis pv. vasculorum & CFBP1289 & Réunion \\
\hline X. axonopodis pv. phaseoli & CIAT306, CIAT072 & Argentina, United States \\
\hline$X$. axonopodis pv. vignicola & $\mathrm{I} 2$ & Niger \\
\hline$X$. axonopodis pv. poinsetticola & UPB073, LMG5403 & India, New Zealand \\
\hline$X$. axonopodis pv. ricini & UPB075, UPB076 & Ethiopia, Hong Kong \\
\hline X. campestris pv. incanae & CFBP1438 & United States \\
\hline$X$. campestris pv. mangiferaeindicae & NCPPB490, 2623, 1117, 2926 & Réunion \\
\hline X. campestris pv. euphorbiae & LMG863, LMG7402 & Sudan \\
\hline$X$. horturum pv. pelargonii & NCPPB2985, CFBP10342 & New Zealand, France \\
\hline X. translucens pv. translucens & UPB545 & Mexico \\
\hline$X$. translucens pv. undulosa & UPB882 & Yemen \\
\hline X. oryzae pv. oryzae & CFBP1948 & Cameroon \\
\hline$X$. albilineans & G7, R8 & Guadeloupe \\
\hline X. cassavae & NCPPB101, UPB037 & Malawi, Rwanda \\
\hline \multicolumn{3}{|l|}{ Other bacterial species } \\
\hline Ralstonia solanacearum & Orst1153, Orst1155, GMI1000 & Congo, Guyana \\
\hline Epiphytic strains & Eight field isolates & Congo \\
\hline
\end{tabular}

${ }^{a}$ CFBP $=$ Collection Française de Bactéries Phytopathogènes, Angers, France; CIAT = Xanthomonas collection, Centro Internacional de Agricultura Tropical, Cali, Colombia; CIO = ORSTOM collection, CIAT, Cali, Colombia; G7 and R8 = Collection CIRAD-CA de Bactéries Phytopathogènes, Montpellier, France; INTA = Collection Instituto Nacional de Tecnologia Agropecuaria, Bella Vista, Argentina; I and K = IITA, International Institute of Tropical Agriculture, Collection Laboratoire de Phytopathologie, Cotonou, Benin; LMG = Laboratorium voor Microbiologie Gent culture collection, Universiteit Gent, Belgium; NCPPB = National Collection of Plant Pathogenic Bacteria, Harpenden, England; Orst = ORSTOM, Collection de Bactéries Phytopathogènes, Laboratoire de Phytopathologie, Montpellier, France; and UPB = Collection Unité de Phytopathologie, Louvain-La-Neuve, Belgium. Strains 2623, 1117, and 2926 of X. campestris pv. mangiferaeindicae were kindly provided by O. Pruvost (CIRAD-FLHOR, Saint Pierre, La Réunion, France). $*=$ Nonpathogenic strain, according to this assay and as previously described (39). 
quences in the nucleotide sequence databases (EMBL, PDB, or GenBank library searches, subdivision bacterial, programs Blast and Fasta) (1). PCR assays were performed with a DNA thermal cycler (PTC-100, MJ Research, Watertown, MA). PCR reactions contained $1.5 \mathrm{mM} \mathrm{MgCl}_{2}$, primer (12.5 pmol), $200 \mu \mathrm{M}$ nucleotides, and 1.25 units of Taq DNA polymerase per $50-\mu$ reaction. The PCR temperature profile comprised an initial denaturation step at $95^{\circ} \mathrm{C}$ for $5 \mathrm{~min}, 30$ cycles of $95^{\circ} \mathrm{C}$ for 30 $\mathrm{s}, 61^{\circ} \mathrm{C}$ for $30 \mathrm{~s}$, and $72^{\circ} \mathrm{C}$ for $1.5 \mathrm{~min}$; and a final extension at $72^{\circ} \mathrm{C}$ for $5 \mathrm{~min}$. $\mathrm{Nu}-$ cleotide sequences of primers used in the PCR reaction are 5'-TTC-GGC-AACGGC-AGT-GAC-CAC-C-3' (primer XV) and 5'-TCA-ATC-GGA-GAT-TAC-CTGAGC-G-3' (primer XK). PCR amplification assays were routinely performed with $20 \mathrm{ng}$ taining $20 \mu \mathrm{l}$ of the PCR amplification product were removed and subjected to electrophoresis in $1 \%$ agarose gels at $50 \mathrm{~V}$ for $1 \mathrm{~h}$ and visualized by ultraviolet light after staining with ethidium bromide.

Detection of $X$. axonopodis pv. manihotis in plant samples. Cassava stems and leaves were collected from infected fields. Leaves were sampled by cutting out the angular lesions, macerating the tissue, and water. Stems were crushed and treated as described above. The extract from each sample was diluted serially in 10-fold increments in distilled water, and $10 \mu \mathrm{l}$ was used in the PCR assay. Leaves of greenhouse-grown cassava were inoculated by placing $10 \mu \mathrm{l}$ of $X$. axonopodis pv. manihotis strains (about $10^{8} \mathrm{CFU} / \mathrm{ml}$; optical density at $600 \mathrm{~nm}=0.1$ ) on the leaf surface in a hole (2-mm diameter) made with a and nonpathogenic $X$. axonopodis pv. manihotis strains were tested with this assay. After 7 days, individual lesions and control tissues were removed around the point of inoculation and macerated in 300 of bacterial genomic DNA. Aliquots consuspending it in $0.5 \mathrm{ml}$ of sterile distilled cork borer (39). In total, eight pathogenic

$\mu \mathrm{l}$ of distilled sterile water. The presence of typical water-soaked angular lesions indicated pathogenicity of an isolate, whereas no reaction was visible with nonpathogenic isolates (39). Of the resulting extracts and dilution series in sterile water, $10 \mu \mathrm{l}$ were used as a source of template DNA and plated on LPG agar, and the colonies that developed were counted.

Assessment of sensitivity thresholds. Aliquots from bacterial suspensions made in sterile water from freshly streaked LPG plates were used as templates in PCR assays. Bacteria were adjusted to $A_{600 \mathrm{~nm}}=$ 0.1 (about $1.2 \times 10^{8} \mathrm{CFU} / \mathrm{ml}$ ), serially diluted in sterile water, and plated on LPG medium to determine the bacterial concentration. From each dilution, $10 \mu \mathrm{l}$ was used for direct amplification in the PCR assay. DNA concentrations were estimated by spectrophotometry at 260 and $280 \mathrm{~nm}$. A dilution series of DNA from $X$. axonopodis pv. manihotis strain CIO46, in the range of $20 \mathrm{ng}$ to $1 \mathrm{fg}$, was prepared and assayed to estimate the limit for detection for purified DNA.

Nucleotide sequence accession number. The nucleotide sequence has been submitted to GenBank and assigned accession number AF012325. The 898-bp target sequence corresponds to nucleotides 4996 to 5894 .

\section{RESULTS}

Primer specificity for detecting $X$. axonopodis pv. manihotis. Primer pair $\mathrm{XV}$-XK directed the amplification of the 898-bp target sequence in DNA from 107 $X$. axonopodis pv. manihotis strains originally isolated in 25 countries (Table 1 and Fig. 1). Five nonpathogenic $X$. axonopodis pv. manihotis strains were tested with the primer pair; the assay produced no amplification product (data not shown). No amplicons were produced from DNA extracted from 46 other strains of bacteria, including 16 strains of six other Xanthomonas species, 19 strains of 14 other patho-

\section{0}

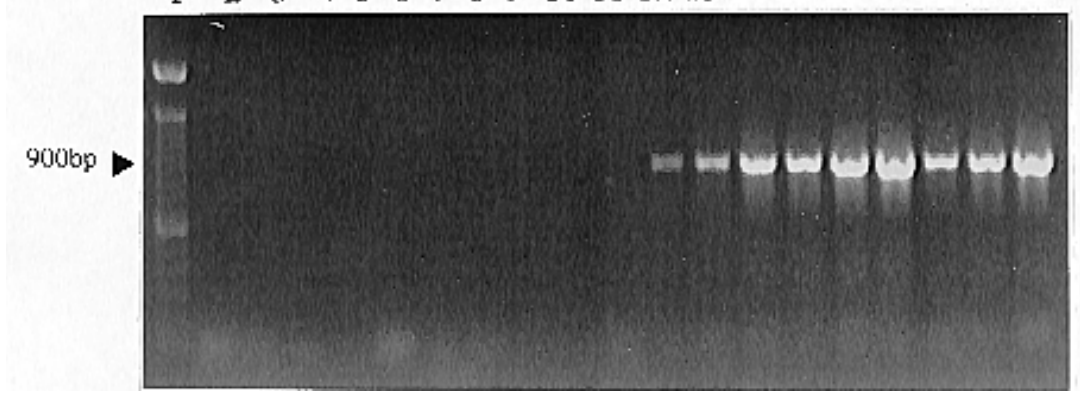

Fig. 1. Agarose gel, stained with ethidium bromide, of DNA products extracted from Xanthomonas strains and amplified by polymerase chain reaction. Lane 1, 100-bp ladder; lane 2, X. albilineans G7; lane 3, X. oryzae pv. oryzae CFBP1948; lane 4, X. axonopodis pv. campestris CFBP10412; lane 5, X. axonopodis pv. aracearum NCPPB2832; lane 6, X. axonopodis pv. glycines NCPPB554; lane 7, X. axonopodis pv. citri CFBP1814; lane 8, X. axonopodis pv. vesicatoria CFBP10601; lane 9, X. axonopodis pv. malvacearum ORST57; lane 10, X. axonopodis pv. ricini UPB075; lane 11, X. cassavae UPB037; lanes 12-20, X. axonopodis pv. manihotis strains I89, Orst200, Orst151, OrstX84, Orst214, Orst215, LMG780, Orst50, and Orst186, respectively. vars of $X$. axonopodis, three strains of Ralstonia solanacearum, or eight epiphytic strains isolated from cassava leaf tissue (Table 1 and Fig. 1; some data not shown).

Sensitivity of PCR amplification. A dilution series of freshly cultured cells of $X$. axonopodis pv. manihotis strain CIO46 yielded a limit of detection of about $1.2 \times$ $10^{2}$ viable cells per reaction, as determined by dilution plating (Fig. 2A). A dilution series of total DNA of $X$. axonopodis pv. manihotis strain CIO46 was prepared and used as template for PCR amplification. Aliquots that contained $10 \mathrm{fg}$ of genomic DNA were successfully detected after amplification with the primer pair XV-XK (Fig. 2B).

Detection of $X$. axonopodis pv. manihotis in plant tissues. PCR was used to detect bacteria in leaf and stem tissues obtained from inoculated plants grown in the greenhouse or from plant samples collected in the field. PCR products were generated from single leaf lesions that were collected in the field, diluted 1,000 times, and then amplified (Fig. 3). The minimum number of viable cells detected by PCR was six per reaction (Fig. 3). The appropriate PCR product was also generated from 8-month-old dry leaf lesions collected in field experiments. The minimum number of cells detected was $3 \mathrm{CFU}$ per reaction in these experiments (data not shown). Amplification of the expected fragment also occurred from extracts of lesions induced by inoculation with different $X$. axonopodis pv. manihotis strains 7 days earlier (data not shown). No prod-
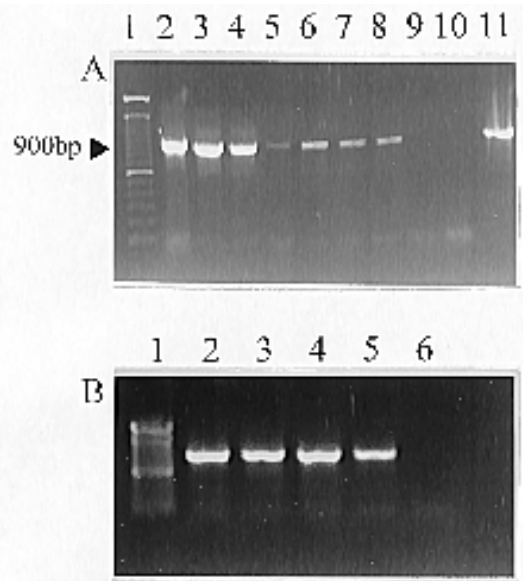

Fig. 2. Agarose gel, stained with ethidium bromide, of products from polymerase chain reaction amplification for a sensitivity assay with Xanthomonas axonopodis pv. manihotis strain CIO46. (A) Lane 1, 100-bp ladder; lane 2, $1.2 \times$ $10^{8} \mathrm{CFU} / 10 \mu \mathrm{l}$; lane $3,1.2 \times 10^{7} \mathrm{CFU} / 10 \mu \mathrm{l}$; lane $4,1.2 \times 10^{6} \mathrm{CFU} / 10 \mu \mathrm{l}$; lane $5,1.2 \times 10^{5}$ $\mathrm{CFU} / 10 \mu \mathrm{l}$; lane $6,1.2 \times 10^{4} \mathrm{CFU} / 10 \mu \mathrm{l}$; lane 7 , $1.2 \times 10^{3} \mathrm{CFU} / 10 \mu \mathrm{l}$; lane $8,1.2 \times 10^{2} \mathrm{CFU} / 10$ $\mu \mathrm{l}$; lanes 9 and 10, negative controls; and lane 11 , DNA strain CIO46 as positive control. (B) Different DNA concentrations of CIO46 strain: lane 1, 100-bp ladder; lane 2, $20 \mathrm{ng} / \mu \mathrm{l}$; lane 3, $10 \mathrm{ng} / \mu \mathrm{l}$; lane 4, $10 \mathrm{pg} / \mu \mathrm{l}$; lane $5,10 \mathrm{fg} / \mu \mathrm{l}$; and lane 6 , negative control (distilled water). 
ucts were observed from leaf tissue inoculated with the nonpathogenic $X$. axonopodis pv. manihotis strain Orst4, nor were viable bacteria recovered from this tissue (data not shown). No products were observed from healthy noninoculated leaf disks assayed as controls (Fig. 3). Extracts prepared from stem lesions of naturally infected plants collected in the field were positive by PCR; a bacterial concentration of about $1.2 \times 10^{3} \mathrm{CFU}$ per reaction was detected (data not shown).

\section{DISCUSSION}

We have developed a PCR-based assay for $X$. axonopodis pv. manihotis, an important and worldwide pathogen of cassava that is subject to international phytosanitary quarantine (20). We used the sequence data of a $X$. axonopodis pv. manihotis pathogenicity gene to design primers. No similarities were found within the $1.2-\mathrm{kb}$ BamHI-EcoRI fragment to known sequences in data banks. This DNA sequence has provided primers specific for $X$. axonopodis pv. manihotis. The expected fragment was amplified only from $X$. axonopodis pv. manihotis strains. No DNA fragments were amplified from the 46 other bacterial strains tested, including six unidentified epiphytes.

The $112 X$. axonopodis pv. manihotis strains tested in this study are from diverse geographic origins (25 countries in South America, Africa, and Asia). The expected fragment was amplified from several Colombian $X$. axonopodis pv. manihotis strains collected in different edaphoclimatic zones. PCR reactions from the 107 pathogenic strains of $X$. axonopodis pv. manihotis tested contained an amplification product of the expected size after gel electrophoresis. In this study, PCR products were not observed for the five nonpathogenic $X$. axonopodis pv. manihotis strains. Little is known about the epidemiological importance of such strains in cassava bacterial blight $(25,39,41)$. The nonpathogenic $X$. axonopodis pv. manihotis strain Orst 4 carries a deletion in the 1.2-kb BamHI-EcoRI fragment (40); thus, the DNA target sequence is absent and not integrated with another part of the genome (40). Whether other nonpathogenic $X$. axonopodis pv. manihotis strains also lack the target plasmid sequence is of research interest.

In practical diagnosis, the ability to differentiate rapidly the nonpathogenic from pathogenic strains (37) is necessary, but very often techniques for such differentiation are not readily available. While the amplification of $h r p$ sequences by PCR is useful for detecting and identifying plantpathogenic xanthomonads $(16,17,35)$, it is the lack of $h r p$ DNA sequences among nonpathogenic xanthomonads that makes this tool efficient (18).

Several authors have developed plasmidbased PCR assays for detecting phytopathogenic bacteria $(2,14,36)$. The risks of using plasmid DNA as a target sequence, either in PCR assays or in epidemiological studies, have been well documented $(7,14)$. However, the sensitivity of detection assays may be enhanced because the plasmidborne sequence can be present in multiple copies per bacterium $(14,22)$. As suggested by Hartung et al. (14), a PCR-based assay that relies on a plasmid DNA target could be misleading if the plasmid is transmissible. Their results tend to demonstrate that plasmids are stably maintained in $X$. axonopodis pv. citri $(14,32)$. For example, cluster analysis with RFLP data of strains of $X$. axonopodis pv. citri reveals similar phylogenies for plasmid and genomic DNA, which is consistent with the plasmids being stably maintained in $X$. axonopodis pv. citri (32). Similar results have been observed with strains of $X$. axonopodis pv. manihotis (33).

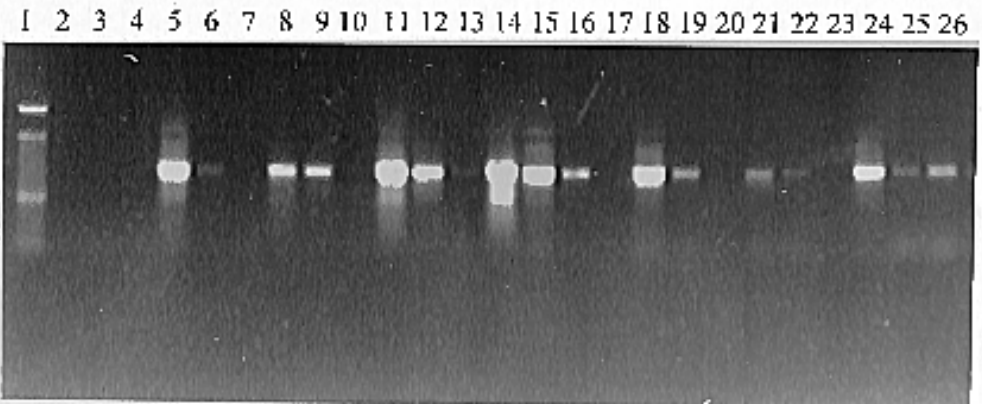

Fig. 3. Agarose gel, stained with ethidium bromide, of polymerase chain reaction amplification products for detecting Xanthomonas axonopodis pv. manihotis in infected cassava leaf tissue. Lane 1, 100-bp DNA ladder; lane 2, negative control (distilled water); lanes 3 and 4, noninoculated leaf tissues; lanes 5-7, 10-fold dilution series from lesion 1, containing $6.4 \times 10^{4}$ to $6.4 \times 10^{2} \mathrm{CFU}$ per reaction; lanes 8-10, 10-fold dilution series from lesion 2, containing $4.5 \times 10^{4}$ to $4.5 \times 10^{2} \mathrm{CFU}$ per reaction; lanes 11-13, 10-fold dilution series from lesion 3, containing $9.2 \times 10^{3}$ to 92 CFU per reaction; lanes 14-16, 10-fold dilution series from lesion 4, containing $9.4 \times 10^{4}$ to $9.4 \times 10^{2} \mathrm{CFU}$ per reaction; lanes 17-19, 10-fold dilution series from lesion 5, containing $6 \times 10^{2}$ to 6 CFU per reaction; lanes 20-22, 10-fold dilution series from lesion 6, containing $1.7 \times 10^{4}$ to $1.7 \times 10^{2} \mathrm{CFU}$ per reaction; lanes 23-25, 10-fold dilution series from lesion 7, containing $1 \times 10^{4}$ to $1 \times 10^{2} \mathrm{CFU}$ per reaction; and lane 26, positive control of DNA from X. axonopodis pv. manihotis strain CIO46.
The PCR procedure is simple to perform, and a 30-cycle, three-step PCR program takes $2 \mathrm{~h}$ to complete. This rapid method is easily adapted for confirming $X$. axonopodis pv. manihotis bacterial colonies and for testing infected plant tissue. PCR detection of $X$. axonopodis pv. manihotis from leaf spots and stem lesions on cassava was successfully conducted without prior DNA extraction. In practice, preparing tissue extracts suitable for PCR requires less than 1 min per sample (crushing), but the time could perhaps be reduced by simply boiling the samples in distilled water (3). The PCR method we used allowed us to detect three viable cells per reaction or the equivalent of $300 \mathrm{CFU} / \mathrm{ml}$ in plant tissue. This is comparable to the levels obtained from PCR techniques available for detecting other phytopathogenic bacteria $(13,14$, $26,28,34)$.

With its specificity and sensitivity, the short PCR assay described here has considerable potential as a reliable procedure for detecting and identifying the cassava bacterial blight pathogen in infected plant tissue. This method will also be applied to detect $X$. axonopodis pv. manihotis in cassava true seeds.

\section{ACKNOWLEDGMENTS}

We are grateful to J. S. Hartung (U. S. Department of Agriculture, Agricultural Research Service, Beltsville, MD) and M. Fregene (CIAT) for critical reading the manuscript and to E. de Paez (CIAT) for editing. We gratefully acknowledge G. Cuny (Laboratoire Rétrovirus, ORSTOM, France) for his fruitful discussions and assistance in sequence analysis. We thank J. P. Geiger (Laboratoire de Phytopathologie Tropicale, ORSTOM, France) and W. Roca and E. Alvarez (CIAT, Cali, Colombia) for their support. Financial support was provided to G. Mosquera by the Instituto Colombiano para el Desarrollo de la Ciencia y la Tecnologia "Francisco José de Caldas" (COLCIENCIAS) in the form of a junior scientist grant.

\section{LITERATURE CITED}

1. Altschul, S. F., Gish, W., Miller, W., Myers, E. W., and Lipman, D. J. 1990. Basic local alignment search tool. J. Mol. Biol. 215:403-410.

2. Audy, P., Braat, C. E., Saindon, G., Huang, H. C., and Laroche, A. 1996. A rapid and sensitive PCR-based assay for concurrent detection of bacteria causing common and halo blights in bean seed. Phytopathology 86:361366.

3. Audy, P., Laroche, A., Saindon, G., Huang, H. C., and Gilbertson, R. L. 1994. Detection of the bean common blight bacteria, Xanthomonas campestris pv. phaseoli and X. c. phaseoli var. fuscans using the polymerase chain reaction. Phytopathology 84:1185-1192.

4. Berthier, Y., Verdier, V., Guesdon, J. L., Chevrier, D., Denis, J. B., Decoux, G., and Lemattre, M. 1993. Characterization of Xanthomonas campestris pathovars by rRNA gene restriction patterns. Appl. Environ. Microbiol. 59:851-859.

5. Boher, B., and Verdier, V. 1994. Cassava bacterial blight in Africa. The state of knowledge and implications for designing control strategies. Afr. Crop Sci. J. 2:1-5.

6. Boher, B., Nicole, M., Potin, M., and Geiger, J. P. 1997. Extracellular polysaccharides from Xanthomonas axonopodis pv. manihotis interact with cassava cell walls during pathogenesis. Mol. Plant-Microbe Interact. 10:803-811. 
7. Canteros, B. I., Minsavage, G. V., Jones, J. B., and Stall, R. E. 1995. Diversity of plasmids in Xanthomonas campestris pv. vesicatoria. Phytopathology 85:1482-1486.

8. Daniel, J. F., and Boher, B. 1981. Contamination of cassava flowers, fruits and seeds by Xanthomonas campestris pv. manihotis. Pages 614-617 in: Proc. Int. Conf. Plant Pathog. Bact., 5th. J. C. Lozano, ed. Centro Internacional de Agricultura Tropical, Cali, Colombia.

9. Daniel, J. F., and Boher, B. 1981. Fluorescent antibody technique for detection of Xanthomonas campestris pv. manihotis. Pages 176180 in: Proc. Int. Conf. Plant Pathog. Bact., 5th. J. C. Lozano, ed. Centro Internacional de Agricultura Tropical, Cali, Colombia.

10. De Boer, S. H., and Ward, L. J. 1995. PCR detection of Erwinia carotovora subsp. atroseptica associated with potato tissue. Phytopathology 85:854-858.

11. Elango, F., and Lozano, J. C. 1980. Transmission of Xanthomonas manihotis in seed of cassava (Manihot esculenta). Plant Dis. 64: 784-786.

12. Hartung, J. S. 1992. Plasmid-based hybridization probes for detection and identification of Xanthomonas campestris pv. citri. Plant Dis. 76:889-893.

13. Hartung, J. S., Daniel, J. F., and Pruvost, O. P. 1993. Detection of Xanthomonas campestris pv. citri by the polymerase chain reaction method. Appl. Environ. Microbiol. 59:11431148.

14. Hartung, J. S., Pruvost, O. P., Villemot, I., and Alvarez, A. 1996. Rapid and sensitive colorimetric detection of Xanthomonas axonopodis pv. citri by immunocapture and a nested-polymerase chain reaction assay. Phytopathology 86:95-101

15. Honeycutt, R., and McClelland, M. 1996. Application of the polymerase chain reaction to the detection of plant pathogens. Pages 187-201 in: The Impact of Plant Molecular Genetics. B. W. S. Sobral, ed. Birchhaüser, Boston.

16. Leite, R. P., Jr., Egel, D. S., and Stall, R. E. 1994. Genetic analysis of hrp-related DNA sequences of Xanthomonas campestris strains causing diseases of citrus. Appl. Environ. Microbiol. 60:1078-1086.

17. Leite, R. P., Jr., Jones, J. B., Somodi, G. C., Minsavage, G. V., and Stall, R. E. 1995. Detection of Xanthomonas campestris pv. vesicatoria associated with pepper and tomato seed by DNA amplification. Plant Dis. 79: 917-922.

18. Leite, R. P., Jr., Minsavage, G.V., Bonas, U., and Stall, R. E. 1994. Detection and identification of phytopathogenic Xanthomonas strains by amplification of DNA sequences related to the hrp genes of Xanthomonas campestris pv. vesicatoria. Appl. Environ. Microbiol. 60:1068-1077.

19. Li, X., and De Boer, S. H. 1995. Selection of polymerase chain reaction primers from an RNA intergenic spacer region for specific detection of Clavibacter michiganensis subsp. sepedonicus. Phytopathology 85:837-842.

20. Lozano, J. C. 1986. Cassava bacterial blight: A manageable disease. Plant Dis. 70:10891093.

21. Maes, M., Garbeva, P., and Kamoen, O. 1996. Recognition and detection in seed of the Xanthomonas pathogens that cause cereal leaf streak using rDNA spacer sequences and polymerase chain reaction. Phytopathology 86:63-69.

22. Mahoney, J. B., Luinstra, K. E., Sellors, J. W., and Cheresky, M. A. 1993. Comparison of plasmid-based and chromosome-based polymerase chain reaction assays for detecting Chlamydia trachomatis nucleic acids. J. Clin. Microbiol. 31:1753-1758.

23. Manulis, S., Valinsky, L., Lichter, A., and Gabriel, D. W. 1994. Sensitive and specific detection of Xanthomonas campestris pv. pelargonii with DNA primers and probes identified by random amplified polymorphic DNA analysis. Appl. Environ. Microbiol. 60:4094-4099.

24. Maraite, H. 1993. Xanthomonas campestris pathovars on cassava: Cause of bacterial blight and bacterial necrosis. Pages 18-24 in: Xanthomonas. J. G. Swings and E. L. Civerolo, eds. Chapman and Hall, London.

25. Maraite, H., Weyns, J., Yimkwan, O., Lipembra, P., and Perreaux, D. 1981. Physiological and pathogenic variations in Xanthomonas campestris pv. manihotis. Pages 358-368 in: Proc. Int. Conf. Plant Pathog. Bact., 5th. J. C. Lozano, ed. Centro Internacional de Agricultura Tropical, Cali, Colombia

26. McManus, P. S., and Jones, A. L. 1995. Detection of Erwinia amylovora by nested PCR and PCR-dot-blot and reverse-blot hybridizations. Phytopathology 85:618-623.

27. Opgenorth, D. C., Smart, C. D., Lows, F. J., de Bruijn, F. J., and Kirkpatrick, B. C. 1996. Identification of Xanthomonas fragariae field isolates by rep-PCR genomic fingerprinting. Plant Dis. 80:868-873.

28. Pan, Y.-B., Grisham, M. P., and Burner, D. M. 1997. A polymerase chain reaction protocol for the detection of Xanthomonas albilineans, the causal agent of sugarcane leaf scald disease. Plant Dis. 81:189-194.

29. Persley, G. J. 1979. Studies on the survival and transmission of Xanthomonas manihotis on cassava seed. Ann. Appl. Biol. 93:159-166.

30. Pooler, M. R., and Hartung, J. S. 1995. Specific PCR detection and identification of Xylella fastidiosa strains causing citrus variegated chlorosis. Curr. Microbiol. 31:377-381.

31. Pooler, M. R., Ritchie, D. F., and Hartung, J. S. 1996. Genetic relationships among strains of Xanthomonas fragariae based on random amplified polymorphic DNA PCR, repetitive extragenic palindromic PCR, and enterobacterial repetitive intergenic consensus PCR data and generation of multiplexed PCR primers useful for the identification of this phytopathogen. Appl. Environ. Microbiol. 62:3121-3127.

32. Pruvost, O., Hartung, J. S., Civerolo, E. L., Dubois, C., and Perrier, X. 1992. Plasmid DNA fingerprints distinguish pathotypes of Xanthomonas campestris pv. citri, the causal agent of citrus bacterial canker disease. Phytopathology 82:485-490.

33. Restrepo, S., and Verdier V. 1997. Geographical differentiation of the population of Xanthomonas axonopodis pv. manihotis in Colombia. Appl. Env. Microbiol. 63:44274434.

34. Roberts, P. D., Jones, J. B., Chandler, C. K., Stall, R. E., and Berger, R. D. 1996. Survival of Xanthomonas fragariae on strawberry in summer nurseries in Florida detected by specific primers and nested polymerase chain reaction. Plant Dis. 80:1283-1288.

35. Stall, R. E., and Minsavage, G. V. 1990. The use of hrp genes to identify opportunistic xanthomonads. Pages 369-374 in: Proc. Int Conf. Plant Pathog. Bact., 7th. Z. Klement, ed. Akadémiai Kiadó, Budapest.

36. Takahashi, Y., Omura, T., Hibino, H., and Sato, M. 1996. Detection and identification of Pseudomonas syringae pv. atropurpurea by PCR amplification of specific fragments from an indigenous plasmid. Plant Dis. 80:783788.

37. Vauterin, L., Yang, P., Alvarez, A., Takikawa, Y., Roth, D. A., Vidaver, A. K., Stall, R. E., Kersters, K., and Swings, J. G. 1996. Identification of non-pathogenic Xanthomonas strains associated with plants. Syst. Appl. Microbiol. 19:96-105.

38. Verdier, V. 1988. Evaluation de la variabilité de Xanthomonas campestris pv. manihotis, agent causal de la bactériose vasculaire du manioc (Manihot esculenta Crantz). Ph.D. thesis. Université de Paris Sud-Orsay, Paris.

39. Verdier, V., Boher, B., Maraite, H., and Geiger, J. P. 1994. Pathological and molecular characterization of Xanthomonas campestris strains causing diseases of cassava (Manihot esculenta). Appl. Environ. Microbiol. 60: 4478-4486

40. Verdier, V., Cuny, G., Assigbétsé, K., Geiger, J. P., and Boucher, C. 1996. Characterization of pathogenicity gene in Xanthomonas campestris pv. manihotis. Abstract G-71 in: Proc. Int. Congr. Mol. Plant Microbe Interact., 8th. G. Stacey, B. Mullin, and P. Gresshoff, eds. Knoxville, TN.

41. Verdier, V., Dongo, P., and Boher, B. 1993. Assessment of genetic diversity among strains of Xanthomonas campestris pv. manihotis. J. Gen. Microbiol. 139:2591-2601.

42. Young, J. M., Saddler, G. S., De Boer, S. H. Vauterin, L., Gardan, L., Gvozdyak, R. I., and Stead, D. E. 1996. Names of plant pathogenic bacteria 1864-1995. Rev. Plant Pathol. 75: 721-763. 